\title{
Anti-Eye Muscle Antibodies and Hypothyroid Graves' Disease: A Case Report
}

\author{
YuJi HIROMATSU, MASAYUKi SATO, KiYOKo TANAKA, \\ KYOHEI NONAKA, KAZUYUKi KOJIMA, Kiminori SATO*, \\ SHINICHI KUROSE**, TOMOAKI HOSHINO***, AND \\ AкIнIKo NAKASHIMA ${ }^{\dagger}$ \\ Division of Endocrinology and Metabolism, Department of \\ Medicine, Department of Radiology, *Department of Otolaryngology, \\ **Department of Ophthalmology, ***Department of Immunology, \\ and ${ }^{\dagger}$ Second Department of Pathology, Kurume University \\ School of Medicine, Fukuoka 830, Japan
}

\begin{abstract}
We report the case of a 70-year-old man who developed hypothyroidism associated with TSH receptor antibodies and severe ophthalmopathy during lithium therapy. He had received lithium therapy for more than 20 years for manic depression, when ophthalmopathy (class VI of the American Thyroid Association classification) and mild hypothyroidism developed. Orbital magnetic resonance imaging indicated marked enlargement of the superior, medial and inferior rectus muscles in the left eye. He had anti-eye muscle antibodies in his serum, detected by Western blotting and quantified by chromatoscanning, as well as anti-TSH receptor antibodies. He was treated with supplementation of levothyroxine and four cycles of methylprednisolone pulse therapy. After the pulse therapy, both anti-eye muscle antibodies and anti-TSH receptor antibodies decreased and disappeared in parallel with the improvement in eye symptoms and signs. These observations suggest the importance of anti-eye muscle antibodies as clinical markers in the development of thyroid-associated ophthalmopathy.
\end{abstract}

Key words: Graves' disease, Ophthalmopathy, Lithium, Thyrotrophin receptor antibody, Eye muscle antibody.

(Endocrinol Japon 39: 593-600, 1992)

THERE is now considerable evidence that thyroidassociated ophthalmopathy (TAO) is an autoimmune disorder [1]. TAO occurs in approximately $85 \%$ of patients with Graves' hyperthyroidism, and occasionally in association with Hashimoto's thyroiditis. To our knowledge, most patients with TAO have detectable serum anti-TSH receptor antibodies, even if they are associated with hypothyroidism [2], although a possible role of anti-TSH receptor antibodies in the development

Received: June 15, 1992

Accepted: October 7, 1992

Correspondence to: Dr. Yuji HIROMATSU, Division of Endocrinology and Metabolism, Department of Medicine, Kurume University School of Medicine, 67 Asahimachi, Kurume, Fukuoka 830, Japan. of ophthalmopathy has never been shown. Eye muscle antibodies as measured in enzyme linked immunosorbent assay [3, 4], antibody-dependent cell-mediated cytotoxicity assay [5] and Western blotting [6-9], have been found in sera from patients with TAO, although their precise roles in the development of TAO are still unclear.

In the present studies, we report a case of so-called "hypothyroid Graves' disease" [10] during lithium therapy. He developed ophthalmopathy and hypothyroidism without a history of hyperthyroidism. He had anti-eye muscle antibodies as well as anti-TSH receptor antibodies before methylprednisolone pulse therapy. After pulse therapy both antibody activities decreased and disappeared, as the symptoms and signs of 
ophthalmopathy improved, suggesting that anieye muscle antibodies may be useful clinical markers in the development of TAO.

\section{Materials and Methods}

Serum free triiodothyronine $\left(\mathrm{T}_{3}\right)$, free thyroxine $\left(\mathrm{T}_{4}\right)$ and thyrotropin ( $\mathrm{TSH}$ ) were measured with commercially available kits (Amerlite Free $\mathrm{T}_{3}$, Amerlite Free $\mathrm{T}_{4}$, Amersham, Tokyo, Japan and Delfia TSH, Pharmacia LKB Biotechnology, Tokyo, Japan, respectively). Anti-thyroglobulin antibodies were measured by a hemagglutination technique with commercial kits (Serodia ATG and Serodia AMC, Fujirebio, Tokyo, Japan). Thyrotropin binding inhibitor immunoglobulins (TBII) were measured by a radioreceptor assay (Baxter, Tokyo, Japan). Thyroid stimulating antibody (TSAB) was measured as the $\%$ increase in cyclic AMP production by FRTL-5 cells $[11]$ and thyroid simulation blocking antibody (TSBAB) was ex- pressed as the \% inhibition of TSH-induced cyclic AMP increase by FRTL-5 cells [12]. Anti-eye muscle antibodies were measured by Western blot analysis. Briefly, sodium dodecyl sulphate polyacrylamide gel electrophoresis (SDS-PAGE) of $100,000 \mathrm{~g}$ membrane fractions of rat eye muscle was carried out under denatured conditions by the method of Laemmli [13] at $35 \mathrm{~mA}$ for $1 \mathrm{~h}$ and 70 $\mathrm{mA}$ for $3 \mathrm{~h}$. Electrotransfer of rat eye muscle membrane proteins onto nitrocellulose paper was performed as described by Towbin et al. [14], with a trans blot cell (Bio-Rad) at 30 volts for $30 \mathrm{~min}$ and 60 volts for $3 \mathrm{~h}$. Then the strips were washed and incubated for $30 \mathrm{~min}$ with 1:25 diluted sera, which were preabsorbed with rat liver acetone powder (SIGMA Chemical Co., St. Louis, Mo., USA) for $1 \mathrm{~h}$. Positive reactivity was developed with commercial kits (Vectastain ABC-GO and a Substrate kit I for glucose oxidase, Vector Laboratories Inc., Burlingame, C.A., USA). To quantify the binding activity of the bands, each strip was chromato-scanned with a Shimadzu CS-930 (Shi-
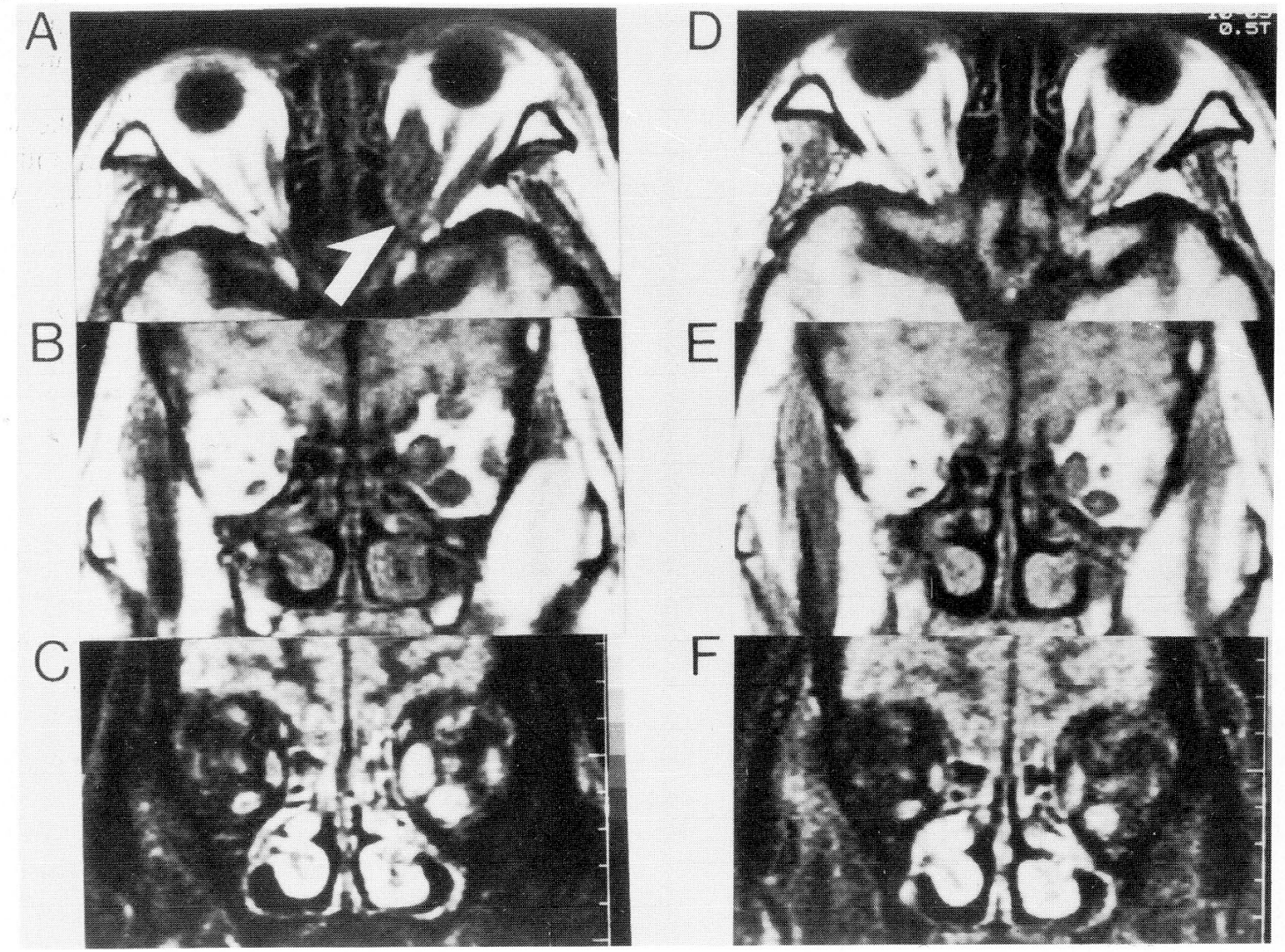

Fig. 1. Orbital MRI before (A, B, C) and after (D, E, F) steroid pulse therapy. Marked enlargement of left medial and inferior rectus muscles and compression of the optic nerve are observed ( $)$. A, D: horizontal section of $\mathrm{T} 1$ weighted images. $\mathrm{B}, \mathrm{E}$ : coronal section of $\mathrm{T} 1$ weighted images. $\mathrm{C}, \mathrm{F}$ : coronal section of STIR images. 
madzu Inc., Kyoto, Japan) [15]. Anti-eye muscle antibody activity was expressed as the ratio of intensity of the positive band at $64 \mathrm{kDa} /$ that of control band which was seen at $66 \mathrm{kDa}$ in all strips as putative endogenous avidin-binding activity. 25 normal subjects, 9 men and 16 women, aged $22-58$ (mean age $30 \pm 9$ years) with no evidence of thyroid disease were tested as the control for anti-eye muscle antibody measurement.

\section{Case Report}

A 70-year-old man was referred to our hospital in December, 1990 because of edema of the left eyelid, exophthalmos and visual disturbance in his left eye. Prior to this, he had been receiving lithium carbonate (200 mg daily) for 20 years because of mania. He had no symptoms suggestive of hyperthyroidism. In August, 1989 he had noticed photophobia, overflow of tears, conjunctival injection and periorbital edema in his left eye.
Ophthalmological treatments (eye drops) gave no relief. Diplopia and an increase in unilateral exophthalmos also developed in May, 1990. In October, 1990 he complained of the loss of visual acuity in the left eye. On physical examination in December 1990, his blood pressure was 120/70 $\mathrm{mmHg}$ and his pulse rate was $76 / \mathrm{min}$. and regular. He was $154 \mathrm{~cm}$ tall and weighed $65 \mathrm{Kg}$. Left unilateral exophthalmos, periorbital edema and conjunctival chemosis were observed. Movements of the left eye were limited in all directions. Visual acuity was $20 / 20$ in the right eye but only perception of hand movement was possible with the left eye. The proptosis was $20 \mathrm{~mm}$ for the left eye and $17 \mathrm{~mm}$ for the right eye with a base line of $102 \mathrm{~mm}$ measured with a Hertel ophthalmometer. Intraocular pressure was $19 \mathrm{mmHg}$ in the left and 18 $\mathrm{mmHg}$ in the right. His eye changes were classified as class VI according to the American Thyroid Association classification [16]. The thyroid gland was not palpable. His voice was hoarse. No abnormality of the heart, chest of abdomen was
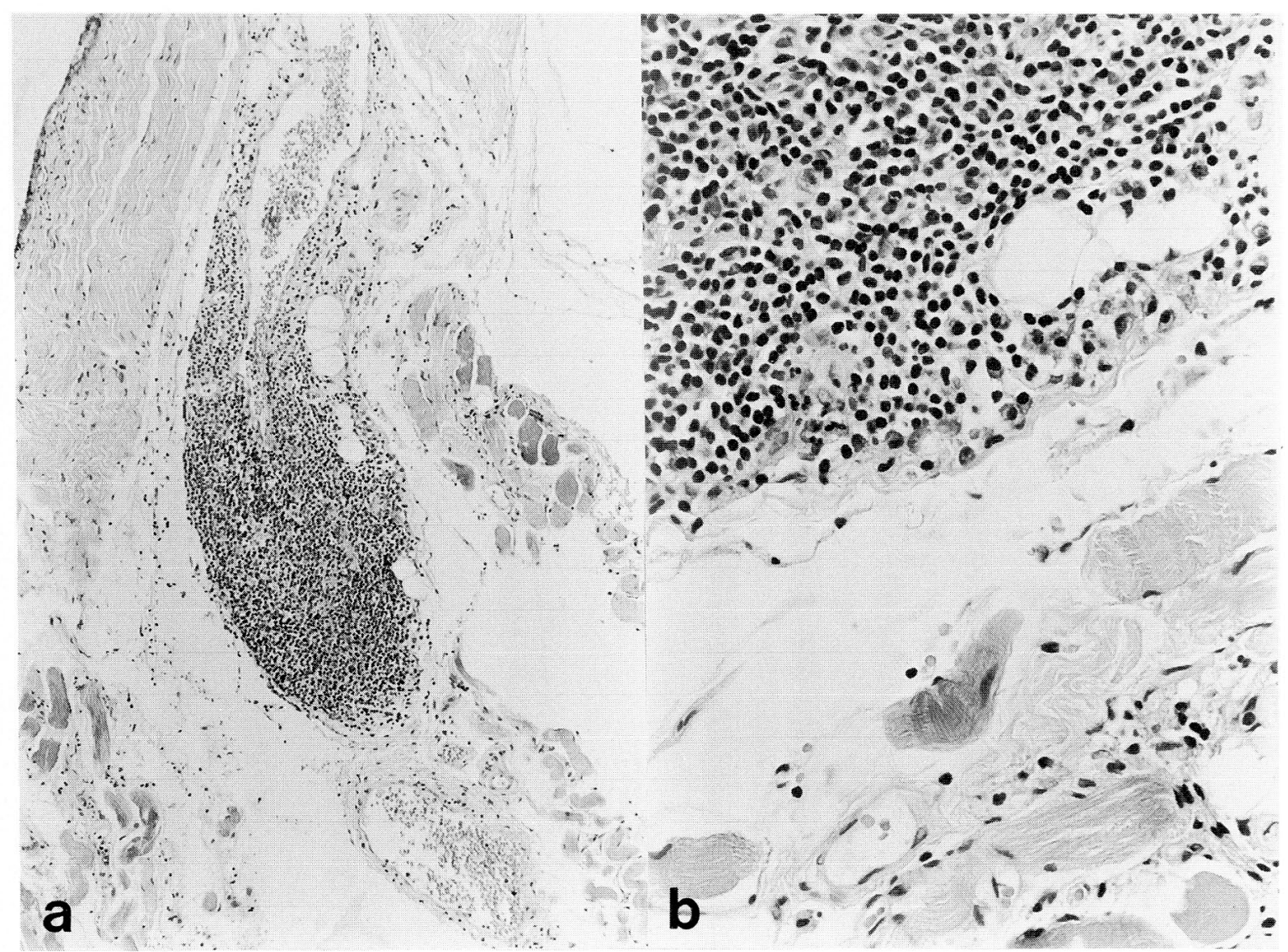

Fig. 2. The biopsy specimen of the enlarged left medial rectus muscle before pulse therapy, showing marked mononuclear cell infiltration around the vessel and interstitial edema. a, HE staining 40 ×; b, HE staining $200 \times$. 
detected. The Achilles tendon reflex showed a slow return. Laboratory studies revealed a normal hemogram and normal values in urinalysis and biochemical tests. Thyroid function studies revealed primary hypothyroidism. Serum free $T_{3}$ was $2.4 \mathrm{pg} / \mathrm{ml}$ and free $\mathrm{T}_{4}$ was $4.4 \mathrm{pg} / \mathrm{ml}$. TSH was $35.39 \mu \mathrm{U} / \mathrm{m} l$. Thyroglobulin was $223 \mathrm{ng} / \mathrm{ml}$. Neither anti-thyroglobulin antibody nor antimicrosomal antibody was detected. Anti-TSH receptor antibodies were positive. The TSH binding inhibitor immunoglobulin (TBII) level was $32.8 \%$ and thyroid stimulating antibody (TSAB), $831 \%$. TSBAB was not detected (-20.6\%). ${ }^{123}$ I uptake was $25.7 \%$ at $5 \mathrm{~h}$ and $22.1 \%$ at $24 \mathrm{~h}$. The plasma lithium level was $1.08 \mathrm{mM}$ (therapeutic range; $0.3-1.5)$.

A computerized tomographic scan of the orbit showed enlargement of the left upper, medial and inferior rectus muscles. MRI also showed enlarge- ment of these eye muscles, and their signal intensities in a short inversion time inversion recovery (STIR) image were increased, suggesting edematous change in the eye muscles (Fig. 1). The eye muscles in the right eye were also enlarged to some extent and their signal intensity in STIR was increased. The left optic nerve was compressed by the enlarged eye muscles, The biopsy specimen of the enlarged left medial rectus muscle before pulse therapy showed marked mononuclear cell infiltration, interstitial edema and some degeneration of muscle fibers (Fig. 2a, 2b). From the immunohistological examination infiltration of both $\mathrm{CD}^{+} \mathrm{T}$ cells and $\mathrm{CD} 8^{+} \mathrm{T}$ cells was observed in the muscle. Both CD45RA ${ }^{+}$cells and CD45RO ${ }^{+}$ cells were present.

The patient was treated with supplementation of levothyroxine (from $25 \mu \mathrm{g}$ to $100 \mu \mathrm{g}$ daily) and given four cycles of methylprednisolone pulse

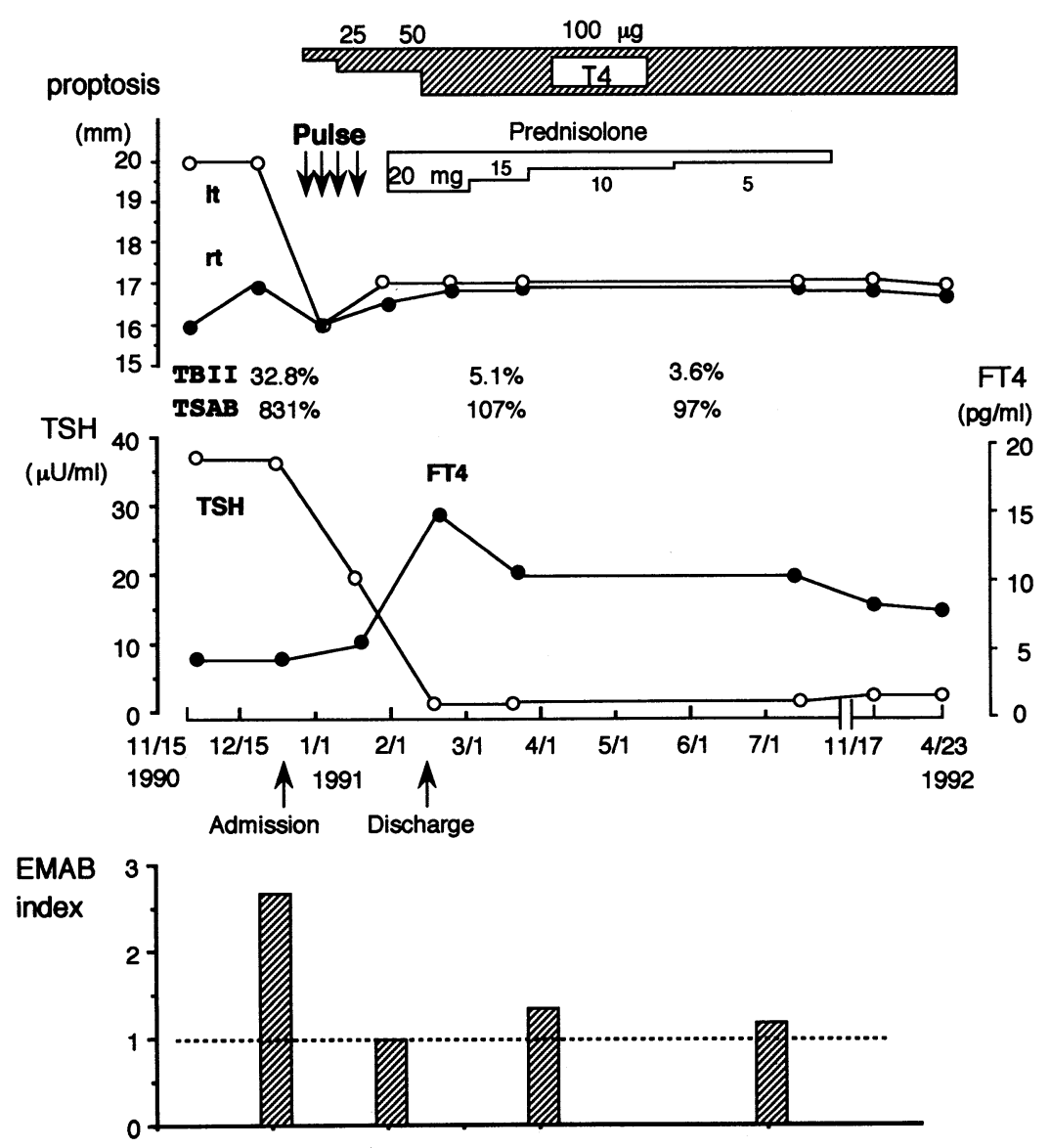

Fig. 3. Clinical course of the patient. EMAB index: Anti-eye muscle antibody activity is expressed as ratio of density of $64 \mathrm{kDa}$ band obtained by chromatoscanning to that of $66 \mathrm{kDa}$ band which is always stained even with sera from normal subjects. The dotted line represents the upper limit of normal (mean + 2SD for 25 normal subjects). 


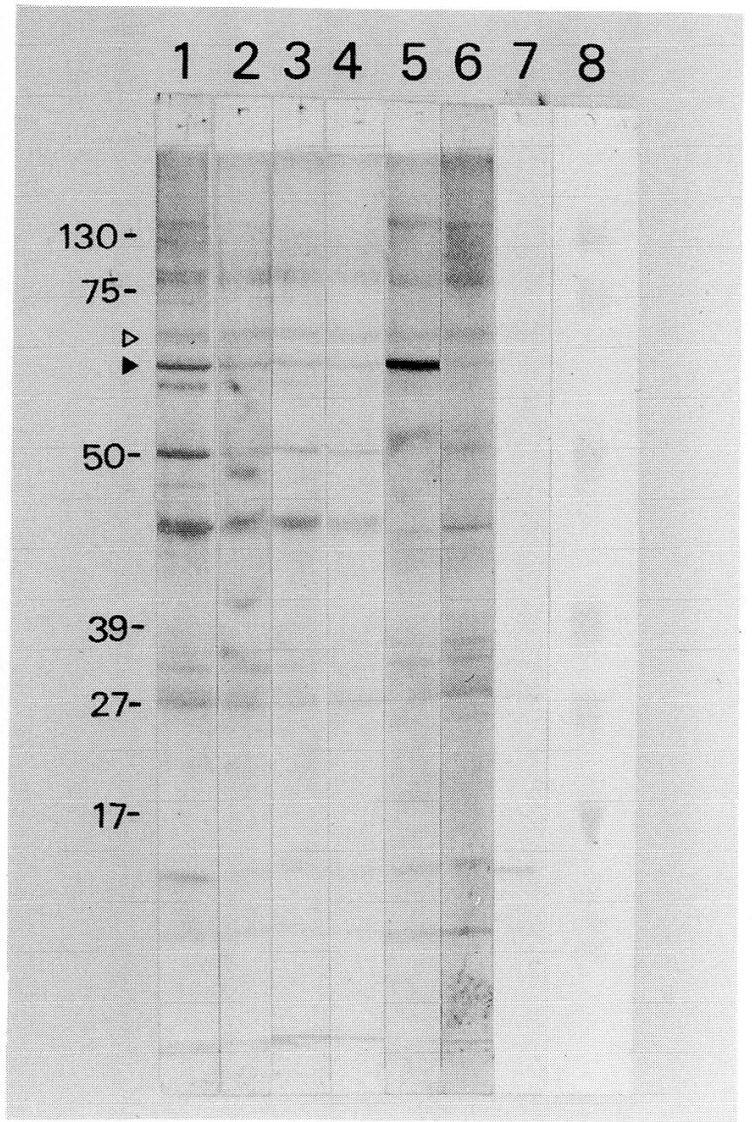

Fig. 4. Anti-eye muscle antibodies to rat eye muscle membrane, detected by Western blotting. Lane 1 to 7 are strips incubated with serum from the patient before (lane 1), 1 month (lane 2), 3 months (lane 3) or 7 months (lane 4) after the pulse therapy, or serum from another TAO patient (lane 5) as positive control, a normal subject (lane 6) as negativc control or phosphate buffered saline (lane 7). Lane 8 indicates molecular weight standard markers. Positive bands at $64(-), 60,48 \mathrm{kDa}$ are seen before the treatment (lane 1). A non-specific band is seen at 66 $\mathrm{kDa}(\triangleright)$ in all strips (lane $1 \sim 7$ ).

therapy ( $1 \mathrm{~g}$ daily intravenous injection of methylprednisolone for three successive days a week as a cycle). The effects of treatment and changes in various immunological and biochemical parameters are summarized in Fig. 3. Periorbital edema was markedly diminished after the first cycle of pulse therapy and proptosis improved to $17 \mathrm{~mm}$ after the second cycle of the therapy. At the end of the fourth cycle of the therapy periorbital edema and chemosis completely disappeared, although, unfortunately, his visual acuity did not improve. A moderate decrease in the dimension and intensity of the affected muscle was observed in orbital MRI (Fig. 1). After pulse therapy, $20 \mathrm{mg}$ prednisolone was given daily for one month and then tapered off. Prednisolone was discontinued at the end of August, 1991. There have been no relapse of any eye symptoms to this time. TBII and TSAB have not been detected in his serum since 3 months after the pulse therapy.

From Western blotting studies it was shown that the serum contained several antibodies to rat eye muscle membranes at 64, 60 and $48 \mathrm{kDa}$ (Fig. 4). The binding activity, expressed as the ratio of the intensity of positive to that of control band, markedly diminished after pulse therapy for all three antibodies.

\section{Discussion}

The occurrence of hypothyroidism in the presence of TSAB may be due to concomitant destructive autoimmune thyroiditis of the administration of lithium for manic depressive disease. Lithium has been reported to inhibit the release of thyroxine from the thyroid glands [17]. Moreover, lithium has been reported to affect the immune system [18, 19]. Weetman et al. [18] demonstrated that lithium increased immunoglobulin synthesis, while Wilson $e t$ al. [19] reported an increased IL-2 production and inhibition of cyclic AMP production of peripheral blood mononuclear cells by lithium. Indeed, patients on lithium had a high incidence of anti-thyroid antibodies (20-24\%) compared to both patients receiving some other forms of treatment for their depression $(7.5 \%)$ [20], and normal subjects (10-14\%) [21]. Segal et al. [22] and Thompson et al. [23] reported the development of TAO during lithium therapy. Therefore, lithium might have initiated the TAO as well as hypothyroidism in the present case.

As shown in Table 1 , most of the patients reported with hypothyroid Graves' disease in the literature had anti-TSH receptor antibodics; 10 of 19 patients had long acting thyroid stimulator (LATS) [10, 24-30], 9 of 12 patients had TBII [2, 31-35] and all 9 patients had TSAB [2, 32-36]. No patient had TSBAB. Although these results suggest a positive relation between ophthalmopathy and anti-TSH receptor antibodies, especially TSAB, there are conflicting reports that TBII do not correlate to the eye disease in Graves' disease [37]. Therefore, the role of anti-TSH receptor antibodies in the development of ophthalmopathy 
Table 1. Anti-TSH receptor antibodies in hypothyroid Graves' disease

\begin{tabular}{llcccc}
\hline \multicolumn{1}{c}{ Author } & LATS & TBII & TSAB & TSBAB & References \\
\hline Liddle & $2 / 2^{*}$ & & & & 24 \\
Fox & $1 / 1$ & & & & 25 \\
Wyse & $1 / 1$ & & & & 26 \\
Michaelson & $1 / 1$ & & & & 27 \\
Lynch & $1 / 1$ & & & & 28 \\
Brownlie & $1 / 10$ & & & & 29 \\
Christy & $2 / 2$ & & & & 10 \\
Sung & $1 / 1$ & & & & 30 \\
Walfish & & $2 / 4$ & $1 / 1$ & & 31 \\
Van Quwerkerk & & $1 / 1$ & $1 / 1$ & $0 / 1$ & 32 \\
Itahashi & & $2 / 2$ & $2 / 2$ & $0 / 2$ & 2 \\
Tamaki & & $1 / 1$ & $1 / 1$ & $1 / 1$ & 33 \\
Saito & & $0 / 1$ & $1 / 1$ & & 34 \\
Ohta & & $2 / 2$ & $2 / 2$ & $0 / 1$ & 35 \\
Hidaka & & $1 / 1$ & $1 / 1$ & $0 / 1$ & \\
Present case & & $9 / 12$ & $9 / 9$ & $1 / 6$ & \\
\hline \multicolumn{1}{l}{ Total } & $10 / 19$ & $9 / 2$ & \\
\hline
\end{tabular}

*Number of positive cases/number of cases tested.

LATS, Long acting thyroid stimulator; TBII, TSH binding inhibitor immunoglobulin; TSAB, Thyroid stimulating antibody; TSBAB, Thyroid stimulation blocking antibody.

is still unclear.

This is the first report of serial examination of anti-eye muscle antibodies by Western blot analysis in hypothyroid Graves' disease. The results suggest a relationship between these antibodies and ophthalmopathy in hypothyroid Graves' disease. In recent years, antibodies to a $64 \mathrm{kDa}$ protein in porcine eye muscle $[7,9]$ and in human eye muscle $[6,8]$ have been reported in TAO. However, Ahmann et al. [7] and Weightman et al. [9] found that normal sera also bound to a $64 \mathrm{kDa}$ protein and argued against the pathological significance of this protein. Conversely, Salvi et al. [6] reported that $50 \%$ of patients with TAO, but no normal subjects, have antibodies against a $64 \mathrm{kDa}$ protein. They further reported that the antibodies also bound to thyroid tissue membranes. More recently Dong et al. [38] reported a cDNA clone encoding a novel $64 \mathrm{kDa}$ protein in the thyroid, and mRNA for this protein was detected in both thyroid and eye muscle, but not in the skeletal muscle in Northern blot analysis. Preliminary studies suggest that this is the same protein as that reported by Salvi et al. [39]. In the present case, we showed the existence of an antibody to $64 \mathrm{kDa}$ protein(s) of rat eye muscle membrane preparations. On the other hand no antibody to rat $64 \mathrm{kDa}$ protein was found in any of 25 normal subjects (Hiromatsu et al., unpublished observation). Moreover we quantified the eye muscle antibody level in serum with a chromatoscanner and showed that anti-eye muscle antibody activity markedly decreased one month after prednisolone pulse therapy, suggesting that the antibody to $64 \mathrm{kDa}$ may be a good clinical marker for the development of ophthalmopathy. Interestingly, a high prevalence of antibodies to the $64 \mathrm{kDa}$ eye muscle membrane antigen in patients receiving lithium therapy has been found in the studies of How and Wall (personal communication). In the present study, antibodies to 60 $\mathrm{kDa}$ and $48 \mathrm{kDa}$ eye muscle membrane were also present in serum before steroid pulse therapy and disappeared after steroid pulse therapy. However, the identity of antigens and the significance of these antibodies are unknown. These antibodies have not been reported in TAO.

In conclusion, although the nature of the 64 $\mathrm{kDa}$ eye muscle membrane antigen, the specificity of the antibody to this antigen and the role of this antibody in the mechanism of the development of TAO need to be further studied, the quantitative measurement of anti-eye muscle antibodies may be useful in evaluating the activity of TAO. The role of lithium in the development of ophthalmopathy is ready to be evaluated. 


\section{References}

1. Wall JR, Salvi M, Bernard NF, Boucher A, Haegert D (1991) Thyroid-associated ophthalmopathy - a model for the association of organ-specific autoimmune disorders. Immunol Today 12: 150-153.

2. Tamaki H, Amino N, Iwatani Y, Miyai K (1989) Improvement of infiltrative ophthalmopathy in parallel with decrease of thyroid-stimulating antibody (TSAB) activity in two patients with hypothyroid Graves' disease. J Endocrinol Invest 12: 47-53.

3. Kodama K, Sikorska H, Bandy-Dafoe P, Bayly R, Wall JR (1982) Demonstration of a circulating autoantibody against soluble eye muscle antigen in Graves' ophthalmopathy. Lancet II: 1353-1356.

4. Kendall-Taylor P, Atkinson S, Holcombe M (1984) A specific $\lg G$ in Graves' ophthalmopathy and its relation to retro-orbital and thyroid autoimmunity. Br Med J 288: 1183-1186.

5. Hiromatsu Y, Fukazawa H, How J, Wall JR (1987) Antibody-dependent cell-mediated cytotoxicity against human eye muscle cells and orbital fibrosis in Graves' ophthalmopathy-roles of Class II MHC antigen expression and $\gamma$-interferon action on effector and target cells. Clin Exp Immunol 70: 597-603.

6. Salvi M, Miller A, Wall JR (1988) Human orbital tissue and thyroid membranes express a $64 \mathrm{kDa}$ protein which is recognized by autoantibodies in serum of patients with thyroid-associated ophthalmopathy. FEBS Lett 232: 135-139.

7. Ahmann A, Baker JR, Weetman AP, Wartofsky L, Nutman TB, Burman KD (1987) Antibodies to porcine eye muscle in patients with Graves' ophthalmopathy; identification of serum immunoglobulins directed against unique determinants by immunoblotting and enzyme-linked immunosorbent assay. J Clin Endocrinol Metab 64: 454-460.

8. Schifferdecker E, Ketzler-Sasse U, Boehm BO, Ronsheimer HB, Scherbaum WA, Schoffling K (1989) Re-evaluation of eye muscle autoantibody determination in Graves' ophthalmopathy:failure to detect a specific antigen by use of enzyme-linked immunosorbent assay, indirect immunofluorescence, and immunoblotting techniques. Acta Endocrinol (Copenh) 121: 643-650.

9. Weightman D, Kendall-Taylor P (1989) Crossreaction of eye muscle antibodies with thyroid tissue in thyroid-associated ophthalmopathy. $J$ Endocrinol 122: 201-206.

10. Christy JH, Morse RS (1977) Hypothyroid Graves' disease. Am J Med 62: 291-296.

11. Kasagi K, Konishi J, Iida Y, Tokuda Y, Arai K, Endo K, Torizuka K (1987) A sensitive and practical assay for thyroid-stimulating antibodies using FRTL-5 thyroid cells. Acta Endocrinol (Copenh) 115: 30-36.

12. Konishi J, Iida Y, Kasagi K, Misaki T, Nakashima T, Endo K, Mori T, Shinpo S, Nohara Y, Matsuura N, Torizuka K (1985) Primary myxedema with thyrotrophin-binding inhibitor immunoglobulins: Clinical and laboratory findings in 15 patients. Ann lntern Med 103: 26-31.

13. Laemmli UK (1970) Cleavage of structural proteins during assembly of the head of bacteriophage T4. Nature 227: 680-684.

14. Towbin H, Staehelin T, Gordon J (1979) Electrophoretic transfer of proteins from polyacrylamide gels to nitrocellulose sheets: procedures and applications. Proc Natl Acad Sci USA 76: 4350-4354.

15. Chinami M, Yuge K, Hachiska H, Tanikawa E, Goto M, Ohtsu Y, Sasai Y, Shingu M (1991) Densitometric determination of human papillomavirus DNA quantities by chromatoscanning in the fluorescence mode. J Virol Methods 32: 101-108.

16. Werner SC (1977) Modification of the classification of the eye changes of Graves' disease: recommendation of the Ad Hoc Committee of the American Thyroid Association. J Clin Endocrinol Metab 44: 203-204.

17. Spaulding SW, Burrow GN, Bermudez F, Himmelloch JM (1972) The inhibitory effect of lithium on thyroid hormone release in both euthyroid and thyrotoxic patients. J Clin Endocrinol Metab 35: 905-911.

18. Weetman AP, McGregor AM, Lazarus JH, Smith BR, Hall R (1982) The enhancement of immunogloblin synthesis by human lymphocytes with lithium. Clin Immunol Immunopathol 22: 400-407.

19. Wilson R, Fraser WD, McKillop JH, Smith J, O'Reilly DS, Thomson JA (1989) The "in vitro" effects of lithium on the immune system. Autoimmunity 4: 109-114.

20. Lazarus LH, John R, Bennie EH, Chalmers RJ, Crockett G (1981) Lithium therapy and thyroid function: a long-term study. Psychol Med 11: 85-92.

21. Tunbridge WMG, Evered DC, Hall R, Appleton D, Brewis M, Clark F, Evans JG, Young E, Bird T, Smith PA (1977) The spectrum of the thyroid disease in a community: the Whickham Survey. Clin Endocrinol (Oxf) 7: 481-493.

22. Segal RL, Rosenblatt S, Eliasoph I (1973) Endocrine exophthalmos during lithium therapy of manic-depressive disease. $N$ Engl J Med 289: $136-138$.

23. Thompson CJ, Baylis PH (1986) Asymptomatic Graves' disease during lithium therapy. Postgrad Med J 62: 295-296.

24. Liddle GW, Heyssel RM, McKenzie JM (1965) 
Graves' disease without hyperthyroidism. Am J Med 39: 845-848.

25. Fox RA, Schwartz TB (1967) Infiltrative ophthalmopathy and primary hypothyroidism. Ann Intern Med 67: 377-380.

26. Wyse EP, McConahey WM, Woolner LB, Scholz DA, Kearns TP (1967) Ophthalmopathy without hyperthyroidism in patients with histologic Hashimoto's thyroiditis. J Clin Endocrinol Metab 38: 1623-1629.

27. Michaelson ED, Young RL (1970) Hypothyroidism with Graves' disease. JAMA 211: 1351-1354.

28. Lynch PJ, Maize JC, Sisson JC (1973) Pretibial myxedema and nonthyrotoxic thyroid disease. Arch Dermatol 107: 107-111.

29. Brownlie BEW, Newton OAG, Singh SP (1975) Ophthalmopathy associated with primary hypothyroidism. Acta Endocrinol (Copenh) 79: 691699.

30. Sung LC, McDougall IR (1978) Graves' hyperthyroidism; spontaneous occurrence after autoimmune hypothyroidism with persistent infiltrative ophthalmopathy. Arch Intern Med 138: 1009-1010.

31. Walfish PG, Gottesman IS, Baxter JL (1982) Graves' ophthalmopathy and subclinical hypothyroidism: diagnostic value of the thyrotrophin releasing hormone test. Can Med Assoc J 127: 291-294.

32. Itahashi H, Naito T, Sato A, Takemura Y (1988) A case of hypothyroidism with marked hypertrophy of external ocular muscles and highly elevated thyroid-stimulating antibody (TSAb). J Jap Soc Inten Med 77: 695-699 (In Japanese).
33. Saito S, Kamijou K, Sato M, Kawasaki K, Tamiuchi A (1990) A case of hypothyroid Graves' disease. Folia Endocrinol Japon 66: 924 (Abstract) (In Japanese).

34. Ohta K, Akasu F, Endo T, Onaya T (1990) A case of hypothyroidism with exophthalmos and positive TSAB but negative TBII. Folia Endocrinol Japon 66 : 924(Abstract) (In Japanese).

35. Hidaka A, Kasai K, Takeuchi A, Hanyu H, lida Y, Misaki T, Endo K, Konishi J (1990) Two cases of hypothyroid Graves' disease. Folia Endocrinol Japon 66: 927 (Abstract) (In Japanese).

36. Van Ouwerkerk BM, Janssens EN, Wijngaarde R, Krenning EP (1983) Severe ophthalmic Graves' disease and autoimmune thyroid disorders with different clinical expression. Neth $J$ Med 26: 176-180.

37. Wall JR, Strakosch CR, Fang SL, Ingbar SH, Braverman LE (1979) Thyroid binding antibodies and other immunological abnormalities in patients with Graves' ophthalmopathy: effect of treatment with cyclophosphamide. Clin Endocrinol (Oxf) 10: 79-91.

38. Dong Q, Ludgate M, Vassart G (1991) Cloning and sequencing of a novel $64-\mathrm{kDa}$ autoantigen recognized by patients with autoimmune thyroid disease. J Clin Endocrinol Metab 72: 1375-1381.

39. Salvi M, Bernard N, Miller A, Zhang ZG, Gardini E, Wall JR (1991) Prevalence of antibodies reactive with a $64 \mathrm{kDa}$ eye muscle membrane antigen in thyroid-associated ophthalmopathy. Thyroid 1: 207-213. 